\title{
Assessment of Genetic Diversity in Okra [Abelmoschus esculentus (L.) Moench]
}

\author{
O.D. Kelemoge ${ }^{1 *}$, P. Ashok ${ }^{1}$, G. Kranthi Rekha ${ }^{1}$ and K. Sasikala ${ }^{2}$ \\ ${ }^{1}$ Department of Horticulture, ${ }^{2}$ Department of Agronomy, Dr. Y.S.R. Horticultural University, \\ Venkataramannagudem, West Godavari - 534 101, A.P., India \\ *Corresponding author
}

\begin{tabular}{|c|}
\hline Keywords \\
\hline $\begin{array}{l}\text { Okra, Genetic } \\
\text { diversity, } \\
\text { Mahalanobis } D^{2} \\
\text { statistics, Cluster }\end{array}$ \\
\hline Article Info \\
\hline $\begin{array}{l}\text { Accepted: } \\
\text { 15 June } 2019 \\
\text { Available Online: } \\
10 \text { July } 2019\end{array}$ \\
\hline
\end{tabular}

A B S T R A C T
The present investigation was carried out at Horticulture Research Station, Dr. Y. S. R Horticultural University, Venkataramannagudem, West Godavari district during kharif season, 2018. Based on $\mathrm{D}^{2}$ values, the twenty-nine hybrids of okra grouped into six clusters. Among the sixclusters, cluster III comprised the maximum number of hybrids (6) followed by cluster II (5), cluster V (5), cluster VI (5), cluster I (4) and cluster IV (4). The maximum inter cluster distance was observed between clusters I and VI $\left(D^{2}=65.06\right)$ followed by clusters II and VI $\left(D^{2}=62.51\right)$. Highest percent contribution towards divergence came from average fruit weight $(17.49 \%)$ followed by fruit yield per plant $(13.30 \%)$, fruit and shoot borer infestation on plants $(12.07 \%)$, plant height $(11.33 \%)$ and number of seeds per fruit $(10.34 \%)$. The data on inter cluster distances suggested that selection of one or two elite genotypes from divergent (I \& VI) and (II \& VI) clusters based on the above characters and crossing them would result in more heterotic and novel hybrids in okra.

\section{Introduction}

Okra (Abelmoschus esculentus (L.) Moench) is a soft woody dicotyledonous herb, which belongs to the family Malvaceae. It is widely cultivated in the tropics and sub-tropics for its tender and nutritious fruits (Chinatu and Okocha, 2006). Okra is a powerhouse of valuable nutrients, low in calories, fat-free and provides a valuable supplementary nutrition in human diet in developing countries (Kumar and Sreeparvathy, 2010). Okra is an often cross-pollinated crop hence heterosis can be exploited to develop new hybrids. To develop high yielding varieties of okra, genetic diversity through Mahalanobis' $\mathrm{D}^{2}$ statistic 
(Mahalanobis, 1936) used as an important tool to select genetically diverse parents with high yield and wider adaptability in breeding programme. Progress of any breeding programmes depends largely on the availability of genetic variability for desirable traits in genotypes (Balai et al., 2014). Genetic diversity helps the breeders in deciding the most appropriate breeding method to increase the genetic potentialities as well as to surpass the yield barrier (Langade et al., 2013). Therefore, genetic diversity is prerequisite for any successful breeding programme. So, the present experiment formulated to study the genetic divergenc eand clustering pattern of the okra hybrids.

\section{Materials and Methods}

The experimental material comprised of 29 hybrids of okra. Thesehybrids evaluated by raising each entry in a plot of $2.5 \mathrm{~m}$ length and $2.5 \mathrm{~m}$ width, at a spacing of $60 \times 45 \mathrm{~cm}$ in a randomized block design with three replications at Horticulture Research Station, Venkataramannagudem during kharif, 2018. The observations were recorded on five randomly selected plants per plot in each replication for seventeen biometric characters viz., plant height $(\mathrm{cm})$, number of primary branches per plant, days to fifty per cent flowering, node at which first flower appear, internodal length of main stem $(\mathrm{cm})$, number of nodes per plant, fruit length $(\mathrm{cm})$, fruit girth $(\mathrm{cm})$, average fruit weight $(\mathrm{g})$, number of fruits per plant, number of seeds per fruit, fruit yield per plant (g), leaf chlorophyll content(SPAD Units), fruit moisture content $(\%)$,mucilage content $(\mathrm{g} / \mathrm{kg})$, fruit and shoot borer infestation (FSB) on fruits (\%) and yellow vein mosaic virus infestation (YVMV) on plants $(\%)$.

The data collected on different characters was analysed using Mahalanobis (1928) $\mathrm{D}^{2}$ analysis to determine the genetic divergence among the hybrids and to classify the hybrids in to different clusters using Ward's method. The character contribution towards genetic divergence was computed using the method given by Singh and Chaudhary (1977).

\section{Results and Discussion}

In this experiment, agglomerative hierarchical clustering technique based on seventeen quantitative characters allocated the twentynine hybrids of okra into six clusters (Table 1 and Fig. 1). The magnitude of $\mathrm{D}^{2}$ values confirmed that there was significant amount of diversity in the experimental material evaluated by the high inter-cluster and low intra cluster $\mathrm{D}^{2}$ values.Cluster III comprised the maximum number of hybrids (6) followed by cluster II (5), cluster V (5), cluster VI (5), cluster I (4) and cluster IV (4).

The inter and intra cluster $\mathrm{D}^{2}$ values presented in Table 2 and Figure 2 showed that the inter cluster average $\mathrm{D}^{2}$ value was maximum between cluster I and cluster VI $\left(\mathrm{D}^{2}=65.06\right)$ followed by cluster II and VI $\left(\mathrm{D}^{2}=62.51\right)$ indicating that the hybrids belonging to these clusters were genetically most divergent. However inter cluster $\mathrm{D}^{2}$ value was least between cluster IV and VI $\left(D^{2}=36.77\right)$ clearly indicating the close relation between the hybrids present in these clusters. Among the six clusters, cluster III showed maximum intra-cluster distance $\left(\mathrm{D}^{2}=29.45\right)$ followed by cluster IV $\left(D^{2}=27.12\right)$ and cluster $I\left(D^{2}=26.57\right)$ whereas lowest intra cluster distance was recorded in cluster VI $\left(D^{2}=20.59\right)$ which may be due to limited gene exchange or selection practices among the hybrids for diverse characters. These results are in accordance with the findings of Singh et al., (2018).

The cluster mean of twenty-nine hybrids presented in the Table 3 revealed that the mean value of clusters varied in magnitude for all the seventeen characters under this study. 
Table.1 Clustering pattern of okra hybrids

\begin{tabular}{|c|c|c|}
\hline Cluster & $\begin{array}{c}\text { No. of } \\
\text { genotypes }\end{array}$ & Genotypes \\
\hline I & 4 & $\begin{array}{c}(\text { Acc-3 } \times \text { Acc-01), }(\text { Acc-3 } \times \text { Acc-40), }(\text { Acc-17 } \times \text { Acc- } 43),(\text { Acc-40 } \times \\
\text { Acc-43) }\end{array}$ \\
\hline II & 5 & $\begin{array}{c}(\text { Acc-3 } \times \text { Acc-41) },(\text { Acc-16 } \times \text { Acc-40), }(\text { Acc-17 } \times \text { Acc-01 }),(\text { Acc-17 } \\
\times \text { Acc-40), }(\text { Acc-41 } \times \text { Acc-01) }\end{array}$ \\
\hline III & 6 & $\begin{array}{c}(\text { Acc-3 } \times \text { Acc-29), }(\text { Acc-16 } \times \text { Acc-17), }(\text { Acc-16 } \times \text { Acc-29), }(\text { Acc-16 } \\
\times \text { Acc-43), }(\text { Acc-1 } \times \text { Acc-29), Mona } 002\end{array}$ \\
\hline IV & 4 & $\begin{array}{c}(\text { Acc-16 } \times \text { Acc-01) },(\text { Acc-40 } \\
\times \text { Acc-29), }(\text { Acc-41 } \times \text { Acc- Ac- } 43),(\text { Acc-43 }\end{array}$ \\
\hline $\mathbf{V}$ & 5 & $\begin{array}{c}(\text { Acc-3 } \times \text { Acc-16) },(\text { Acc-3 } \times \text { Acc-17), }(\text { Acc-17 } \times \text { Acc-41) },(\text { Acc-40 } \times \\
\text { Acc-41), }(\text { Acc-41 } \times \text { Acc-29) }\end{array}$ \\
\hline VI & 5 & $\begin{array}{c}(\text { Acc-3 } \times \text { Acc-43), } \\
\text { (Acc-16 } \times \text { Acc-41), }(\text { Acc-17 } \times \text { Acc-29), },(\text { Acc-40 } \\
\text { Acc- }(\text { Acc-43 } \times \text { Acc-01) }\end{array}$ \\
\hline
\end{tabular}

Table. $2 \mathrm{D}^{2}$ Inter and intra cluster distances of okra hybrids: Ward

\begin{tabular}{|l|l|l|l|l|l|l|}
\hline Cluster & 1 Cluster & 2 Cluster & 3 Cluster & 4 Cluster & 5 Cluster & 6 Cluster \\
\hline $\mathbf{1}$ Cluster & $\underline{\mathbf{2 6 . 5 7}}$ & 38.99 & 39.53 & 50.70 & 44.89 & $\mathbf{6 5 . 0 6}$ \\
\hline $\mathbf{2}$ Cluster & & $\underline{\mathbf{2 6 . 0 6}}$ & 39.39 & 41.29 & 44.62 & $\mathbf{6 2 . 5 1}$ \\
\hline $\mathbf{3}$ Cluster & & & $\underline{\mathbf{2 9 . 4 5}}$ & 38.73 & 37.99 & $\mathbf{4 8 . 2 3}$ \\
\hline $\mathbf{4}$ Cluster & & & & $\underline{\mathbf{2 7 . 1 2}}$ & 48.44 & $\mathbf{3 6 . 7 7}$ \\
\hline $\mathbf{5}$ Cluster & & & & & $\underline{\mathbf{2 5 . 3 7}}$ & $\mathbf{3 8 . 8 7}$ \\
\hline 6 Cluster & & & & & & $\underline{\mathbf{2 0 . 5 9}}$ \\
\hline
\end{tabular}


Table.3 Cluster mean for seventeen characters of okra hybrids: Tocher's method

\begin{tabular}{|c|c|c|c|c|c|c|}
\hline \multirow[t]{2}{*}{ Character } & \multicolumn{6}{|c|}{ Clusters } \\
\hline & I & II & III & IV & V & VI \\
\hline Plant Height (cm) & 83.86 & 99.32 & 62.13 & 61.07 & 89.20 & 106.40 \\
\hline $\begin{array}{l}\text { Number of primary branches per } \\
\text { plant }\end{array}$ & 2.90 & 2.83 & 3.20 & 2.67 & 3.27 & 2.73 \\
\hline Internodal Length of Main Stem (cm) & 6.55 & 7.39 & 5.03 & 4.53 & 7.27 & 9.40 \\
\hline Number of nodes per plant & 13.14 & 13.81 & 11.33 & 15.40 & 12.93 & 11.90 \\
\hline Days to $50 \%$ Flowering & 42.78 & 42.60 & 42.33 & 42.67 & 44.33 & 43.33 \\
\hline $\begin{array}{l}\text { Node at which first flower appears } \\
\text { (no.) }\end{array}$ & 4.31 & 4.24 & 4.00 & 4.20 & 4.27 & 4.20 \\
\hline Fruit Length $(\mathbf{c m})$ & 13.38 & 13.07 & 13.73 & 13.00 & 11.23 & 12.70 \\
\hline Fruit Girth $(\mathbf{c m})$ & 6.83 & 6.81 & 7.50 & 7.30 & 6.93 & 6.53 \\
\hline Average Fruit Weight (g) & 14.84 & 21.55 & 18.40 & 14.23 & 18.47 & 14.40 \\
\hline Number of fruits per plant & 17.87 & 20.96 & 16.20 & 15.80 & 20.00 & 16.80 \\
\hline Number of Seeds per fruit & 56.26 & 54.34 & 58.53 & 53.40 & 56.80 & $\mathbf{5 3 . 8 0}$ \\
\hline $\begin{array}{l}\text { Leaf Chlorophyll Content (SPAD } \\
\text { Units) }\end{array}$ & 45.62 & 45.86 & 40.87 & 41.63 & 47.17 & 49.03 \\
\hline Mucilage Content (g/kg) & 8.08 & 7.84 & 7.58 & 7.06 & 9.10 & 7.40 \\
\hline Fruit moisture content (\%) & 89.08 & 87.79 & 90.29 & 88.44 & 92.75 & 88.41 \\
\hline YVMV Infestation on Plants (\%) & 10.62 & 9.81 & 12.59 & 6.67 & 0.00 & 5.19 \\
\hline FSB Infestation on Fruits (\%) & 10.93 & 8.60 & 10.15 & 10.64 & 2.06 & 6.08 \\
\hline Fruit Yield Per Plant (g) & 249.63 & 290.62 & 225.53 & 211.80 & 266.73 & 245.87 \\
\hline
\end{tabular}


Table.4 Relative contribution of different characters towards genetic divergence

\begin{tabular}{|l|c|c|}
\hline Character & Contribution (\%) & Times ranked first \\
\hline Plant Height (cm) & 11.33 & $\mathbf{4 6}$ \\
\hline $\begin{array}{l}\text { Number of primary branches per } \\
\text { plant }\end{array}$ & 2.96 & $\mathbf{1 2}$ \\
\hline $\begin{array}{l}\text { Internodal Length of Main stem } \\
\text { (cm) }\end{array}$ & 4.43 & $\mathbf{1 8}$ \\
\hline Number of nodes per plant & 0.25 & $\mathbf{1 1}$ \\
\hline Days to 50 \% Flowering & 5.17 & $\mathbf{1 1}$ \\
\hline $\begin{array}{l}\text { Node at which first flower } \\
\text { appears (no.) }\end{array}$ & 2.71 & $\mathbf{1 2}$ \\
\hline Fruit Length (cm) & 2.96 & $\mathbf{4}$ \\
\hline Fruit Girth (cm) & 0.99 & $\mathbf{7 1}$ \\
\hline Average Fruit Weight (g) & 17.49 & $\mathbf{1 5}$ \\
\hline Number of fruits per plant & 3.69 & $\mathbf{1 2}$ \\
\hline Number of seeds per fruit & 10.34 & $\mathbf{1 2}$ \\
\hline Leaf chlorophyll content (SPAD & 0.25 & $\mathbf{1 2}$ \\
\hline Units) & 2.96 & $\mathbf{1 3}$ \\
\hline Mucilage Content (g/kg) & 2.96 & \\
\hline Fruit moisture content (\%) & 12.07 & \\
\hline Fruit Yield Per Plant (g) & & \\
\hline
\end{tabular}




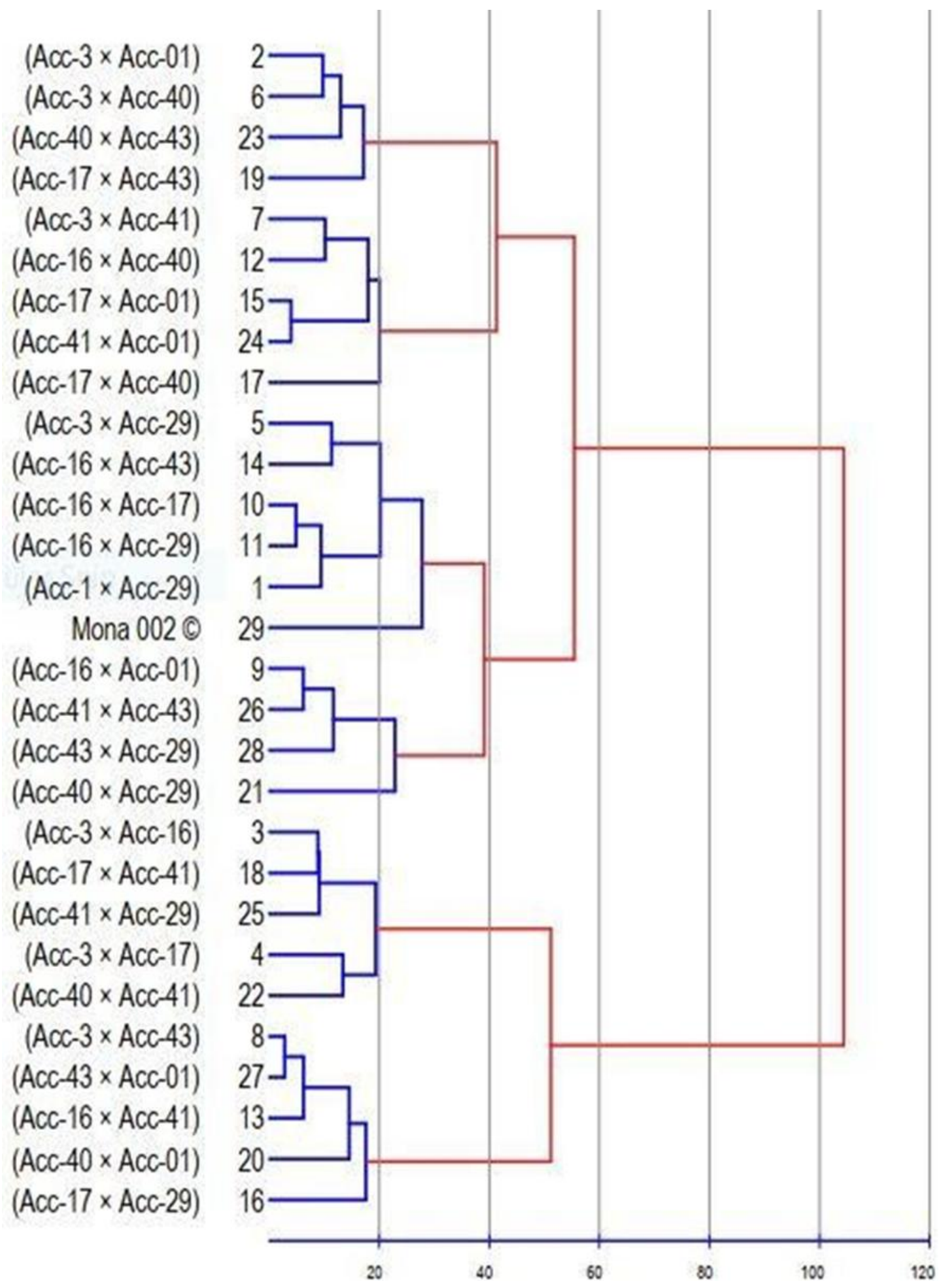

Figure 1: Mahalanobis average linkage dendogram depicting clustering in 29 genotypes of okra 


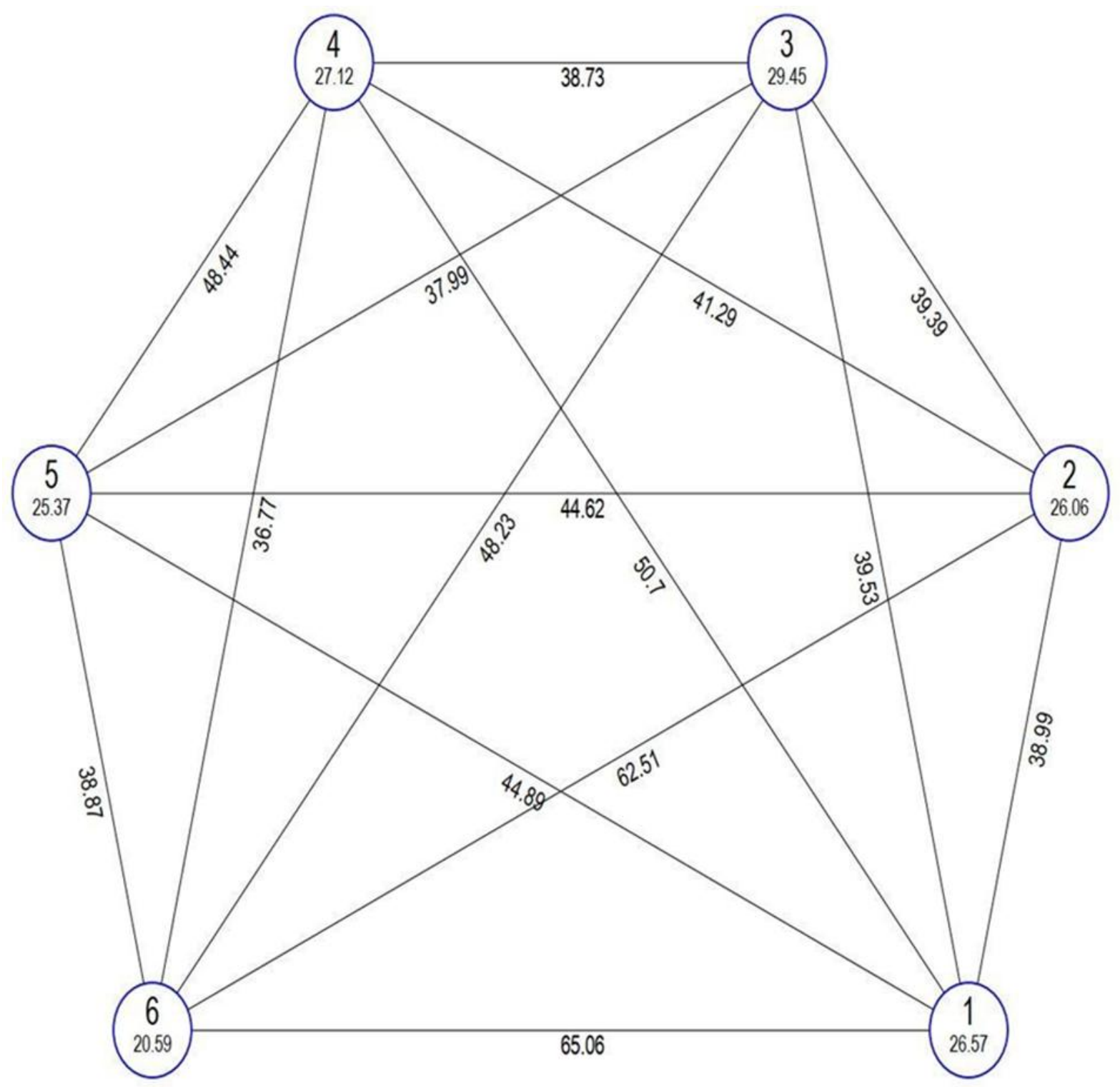

Figure 2: Ward's Minimum Variance Distance Matrix.

Cluster II exhibited highest cluster mean values for various characters viz., fruit yield per plant (290.62), average fruit weight (21.55) and number of fruits per plant (20.96), whereas Cluster III contained highest mean values for number of seeds per fruit (58.53), fruit length (13.73), and fruit girth (7.50). Cluster IV recorded the highest mean for only one character, which was number of nodes per plant (15.40). Cluster V contained highest mean values for fruit moisture content (92.75), mucilage content (9.10) and number of primary branches per plant (3.27). Cluster VI had the highest cluster mean values for plant height (106.40) and leaf chlorophyll content (49.03). Lower mean values for 
yellow vein mosaic virus infestation on plants and fruit and shoot borer infestation on fruits are desirable as they are an indication of resistance or tolerance. Cluster $\mathrm{V}$ recorded the lowest mean values for yellow vein mosaic virus infestation on plants (0.00) and fruit and shoot borer infestation on fruits (2.06). Similar results were reported by Chandramouli (2015). Days to 50 per cent flowering and node at which first flower appears are the indicators of earliness in okra. Low mean value is highly desirable for these two attributes of earliness. Cluster III recorded the lowest mean values for days to 50 per cent flowering (42.33) and node at which first flower appears (4.00). Low mean value is desirable for internodal length to accommodate more number of nodes and to get higher fruit yield in okra. Cluster IV recorded the lowest mean value for internodal length of main stem (4.53).

The percentage contribution of different important traits towards the genetic divergence presented in Table 4 revealed that among all the characters, average fruit weight contributed maximum percentage (17.49\%) towards genetic divergence followed by fruit yield per plant $(13.30 \%)$, fruit and shoot borer infestation on plants $(12.07 \%)$, plant height $(11.33 \%)$ and number of seeds per fruit $(10.34 \%)$.Henceforth targeting the characters that were highly contributing towards divergence might promote the diversity in crop improvement.

Statistical distance represents the extent of genetic diversity among clusters. The results of multivariate analysis resulted in distribution of 29 hybrids into 6 clusters. Among the 6 clusters, cluster III showed maximum intra-cluster distance followed by cluster IV and cluster I whereas the lowest intra cluster distance was recorded in cluster VI. Maximum inter cluster distance was found between cluster I and VI indicating that the hybrids belonging to cluster I were far away from those of cluster VI. However inter cluster distance was least between cluster IV and VI. Average fruit weight contributed maximum percentage towards genetic divergence followed by fruit yield per plant, fruit and shoot borer infestation on plants, plant height and number of seeds per fruit.

\section{References}

Balai, T.C., Maurya, I.B., Shankar, V. and Kumar, N. 2014. Correlation, and Path Analysis in Genotypes of Okra (Abelmochus esculentus (L.) Moench.). The Bioscan. 9(2): 799-02.

Chandramouli, B. 2015. Studies on genetic variability, heritability, correlation and path coefficient analysis in okra (Abelmoschus esculentus (L.) Moench) genotypes. MSc thesis. College Of Horticulture, Dr. Y. S. R. Horticultural University.

Chinatu, L.N. and Okocha, P.I. 2006. Prospect of Increased Production of Okra (Abelmoschus esculentus (L.) Moench) Through Heterosis. Journal of Sustainable Tropical Agricultural Research. 17: 66-71.

Kumar, P.S. and Sreeparvathy, S. 2010. Studies on Heterosis in Okra (Abelmoschus esculentus (L.) Moench). Electronic Journal of Plant Breeding. 1(6): 1431-33.

Langade, D. M., Ram, C. N., Vishwakarma, D. N. and Sharma, A. 2013. Evaluation of genetic divergence in berseem (Trifolium alexandrinum L.) germplasms. The Bioscan. 8 (3): 76770 .

Mahalanobis, P. C. 1928. A statistical study of Chinese head measurement. Man in India. 8: 32-64.

Mahalanobis, P.C. 1936. On the generalized distance in statistics. Proceedings of 
National Academy of Sciences in India. 2: 49-55.

Singh, D., Dudi, B.S., Dhankhar, S.K. and Rajkumar. 2018. Genetic diversity analysis of okra genotypes using morphological markers. International
Journal of Current Microbiology and Applied Sciences. 7(1): 1667-75.

Singh, R.K. and Chaudhary, B.D. 1977. Biometrical Methods in Quantitative Genetic Analysis. Kalyani Publishers, New Delhi. 215-18.

\section{How to cite this article:}

Kelemoge, O.D., P. Ashok, G. Kranthi Rekha and Sasikala, K. 2019. Assessment of Genetic Diversity in Okra [Abelmoschus esculentus (L.) Moench]. Int.J.Curr.Microbiol.App.Sci. 8(07): 1923-1931. doi: https://doi.org/10.20546/ijcmas.2019.807.229 